\title{
Modelling localized sources of sediment in mountain catchments for provenance studies
}

\author{
Giulia Battista ${ }^{1}$, Fritz Schlunegger ${ }^{2}$, Paolo Burlando ${ }^{1}$, and Peter Molnar ${ }^{1}$ \\ ${ }^{1}$ Institute of Environmental Engineering, ETH Zurich, Switzerland \\ ${ }^{2}$ Institute of Geology, University of Bern, Switzerland
}

\begin{abstract}
A hydrology-sediment modelling framework based on the model Topkapi-ETH combined with basin geomorphic mapping is used to investigate the role of localized sediment sources in a mountain river basin (Kleine Emme, Switzerland). The periodic sediment mobilization from incised areas and landslides by hillslope runoff and river discharge is simulated in addition to overland flow erosion to quantify their contributions to suspended sediment fluxes. The framework simulates the suspended sediment load provenance at the outlet and its temporal dynamics, by routing fine sediment along topographically-driven pathways from the distinct sediment sources to the outlet. We show that accounting for localized sediment sources substantially improves the modelling of observed sediment concentrations and loads at the outlet compared to overland flow erosion alone. We demonstrate that the modelled river basin can shift between channel-process and hillslope-process dominant behaviour depending on the model parameter describing gully competence on landslide surfaces. The simulations in which channel processes dominate were found to be more consistent with observations, and with two independent validations in the Kleine Emme, by topographic analysis of surface roughness and by sediment tracing with ${ }^{10} \mathrm{Be}$ concentrations. This research shows that spatially explicit modelling can be used to infer the dominant sediment production process in a river basin, to inform and optimise sediment sampling strategies for denudation rate estimates, and in general to support sediment provenance studies.
\end{abstract}

KEYWORDS: sediment sources; sediment provenance; mountain basin; cosmogenic radionuclides; suspended sediment transport modelling; mesoscale catchment

\section{${ }_{21} 1$ Introduction}

22 Suspended sediment load is generated by several types of mobilization processes that act on hillslopes and ${ }_{23}$ in channels, such as landslides, debris flows, overland flow erosion, river bed and bank erosion, the signal of 24 which is filtered by the transport processes in the river network [e.g. Jerolmack and Paola, 2010, Bracken 25 et al., 2015]. Given the strong nonlinearity and stochasticity of the involved processes, the magnitude of 
sediment load at a river basin outlet and its provenance, i.e. the origin of the sediment delivered to the outlet from different sources, are very difficult to predict [e.g. Roering et al., 1999, Phillips, 2011]. At the same time, such information is of fundamental importance to identify the locations of strongest soil erosion and sediment production, and to determine the downstream effects of the mobilized sediment.

A widely used approach in sediment provenance studies are fingerprinting methods, which allow quantification of the relative contributions of sediment sources to the outlet sediment load, by means of measurable and conservative sediment properties [Haddadchi et al., 2013, Walling, 2005]. Fingerprinting methods have been used to demonstrate the blocking of parts of the catchment from sediment production [e.g. Stutenbecker et al., 2018, 2019], the role of valley gradient in the hillslope-channel geomorphic coupling [e.g. D'Haen et al., 2013] and the correlation between rainfall properties and sediment export [e.g. Navratil et al., 2012]. However, these methods only provide limited information about the actual sediment pathways from source to the outlet and the temporal dynamics of the sediment load composition.

Information about sediment provenance is also essential for denudation rate studies based on cosmogenic radionuclide $(\mathrm{CRN})$ dating. CRN concentrations in river bed samples are used to estimate catchment-average long-term denudation rates, under the assumptions that a sediment sample taken at the river outlet is representative of the long-term erosion rates of the upstream part of the basin, and that the different areas of the basin are represented in the sample proportionally to their erosion rates [von Blanckenburg, 2005, Yanites et al., 2009]. These conditions are especially difficult to be satisfied in mountainous environments, where soil erosion is highly episodic and localized, often dominated by mass movements, and where sediment production from small areas can temporarily dominate the basin sediment load [e.g. Korup et al., 2004, Evrard et al., 2011, Delunel et al., 2014, Cruz Nunes et al., 2015]. Therefore, information about preferential sediment production areas and the hydrological conditions that activate them is key to correctly interpret CRN concentrations in river bed samples in mountainous environments.

One way to quantify the activation of localized sediment sources by time-dependent overland and channel flow, and to track sediment from origin to outlet, is by physically-based spatially-distributed hydrological and sediment transport modelling [de Vente et al., 2006, Kim and Ivanov, 2014, Tsuruta et al., 2018, Battista et al., 2020]. Research has shown that widely used conceptual approaches to spatial erosion estimation, such as RUSLE [Renard et al., 1997] and WaTEM/SEDEM [Van Rompaey et al., 2001] fail in catchments where landslides, bank and gully erosion are expected to play an important role in sediment mobilization [Van Rompaey et al., 2005, Borrelli et al., 2014, 2018]. Some spatially-distributed models already include localized mass wasting processes, e.g. landslides, as a sediment source in addition to diffuse hillslope erosion processes [e.g. Bathurst and Burton, 1998, Doten et al., 2006, Coulthard et al., 2013]. However, they do not explicitly track the sediment produced by the different sediment sources in space and time and therefore cannot reconstruct the sediment provenance at the outlet. 
The aim of this work is to provide an approach that combines spatially explicit hydrology-sediment modelling with detailed knowledge of localized sediment sources, in order to track sediment produced by them to the outlet. In particular, (1) we combine a recently developed distributed hydrology-sediment numerical model [Battista et al., 2020] with detailed basin geomorphic mapping of main sediment production areas in a pre-Alpine river basin, (2) we show with this model how the relative contributions of landslide, hillslope and channel production processes to the fine suspended sediment load at the outlet are affected by parameter choices, (3) we use the model together with surface topographic analysis of landslide areas and measured CRN concentrations in the production zones as a tracer, to independently validate the sediment load composition in the study catchment, and (4) we discuss how the time-dependent modelling of sediment load composition can be used to guide the sampling of CRN for denudation rate estimates and complement fingerprinting approaches.

The hydrology-sediment model is the two-dimensional high-resolution catchment hydrology model TOPKAPI-ETH [Paschalis et al., 2014, Fatichi et al., 2015] with a new suspended sediment module recently introduced by Battista et al. [2020]. The latter showed that high suspended sediment concentrations in the same study catchment were difficult to model by only accounting for diffuse overland flow erosion, and suggested the need to include mass wasting processes with a threshold behaviour. In this work we introduced sediment mobilization from landslides and channel inner gorges as additional erosion processes and fine sediment sources. We introduced a new parameter for sediment mobilization by overland flow on landslide surfaces, the so-called gully competence parameter, to regulate the relative contribution of landslides and incised areas to total sediment yield. We show how this parameter can potentially be estimated from surface roughness derived from a high resolution DEM or by measurements of a sediment source tracer such as the ${ }^{10}$ Be concentrations. We close the paper with a discussion of how this approach can guide optimal riverbed sediment sampling strategies of CRN for denudation rate estimates, and in combination with fingerprinting methods can increase our understanding of the sediment dynamics in a mountain environment.

\section{Data and Methods}

\subsection{Catchment geomorphic mapping}

The case study basin is the Kleine Emme, a $477 \mathrm{~km}^{2}$ pre-Alpine basin located in central Switzerland. The basin has been moderately geomorphically active and is characterized by several inner gorges and knickpoints, expressions of erosional waves generated by the lowering of the base level of the river network following the Last Glacial Maximum [Schlunegger and Schneider, 2005, Van den Berg and Schlunegger, 2012, Dürst Stucki et al., 2012]. In the gorges, deep river incision in the valley floor generates steep river banks characterized by frequent debris flows and bank failures, delivering abundant regolith to 
the river. The exposure of bedrock in these gorges indicates an efficient and supply-limited sediment transport regime in the channels [Schwab et al., 2008]. On the hillslopes, several mass movements like earthflows and landslides are present. The sediment produced by these processes is stored on the hillslopes for potentially long time periods and is only delivered to the river network when short-lived and rare episodes of hillslope-channel coupling take place, consisting mostly of superimposed debris flows [Schwab et al., 2008, Clapuyt et al., 2019]. This mechanism indicates a transport-limited regime on the hillslopes.

We identified the areal extent of the localized sediment sources by geomorphic mapping. Landslides and earth flows $(L S)$ were identified in the Geological Atlas of Switzerland (GeoCover V2) and verified with a high resolution $2 \mathrm{~m}$ LIDAR DEM (SwissAlti3d). Slopes from the LIDAR DEM were used to manually map the extent of areas deeply incised by the river, referred to as incised areas $(I)$ (see map in Fig. 1). The $L S$ and $I$ areas were considered as potential hotspots of fine sediment production as they have abundant clay, silt and fine sand available for transport, and are localized as they cover only $16 \%$ of the entire catchment area.

[Figure 1 about here.]

\subsection{Modelling concept for localized sediment sources}

The hydrology module in Topkapi-ETH is physically based and fully distributed, i.e. raster-based, and it simulates runoff on hillslopes and in the channels, and subsurface flow in a multi-layered soil, from climatic inputs (precipitation, air temperature, cloud cover) and watershed surface and subsurface properties (DEM, soils, vegetation cover). It includes all relevant hydrological processes in alpine environments, such as infiltration and saturation excess runoff formation, soil moisture limited evapotranspiration, snow accumulation and melt, etc. For more model details see Fatichi et al. [2015]. The sediment module in Topkapi-ETH simulates erosion by overland flow on the hillslopes ( $O F$ process) and is based on a transport capacity approach, where at cell level the sediment production rate (erosion) adjusts to the local transport capacity $T_{c}$ :

$$
T_{c}=\alpha \cdot q_{O F}^{1.4} \cdot S^{1.4},
$$

where $T_{c}$ is the specific sediment transport capacity of overland flow per unit area $\left[\mathrm{kg} \mathrm{m}^{-2} \mathrm{~s}^{-1}\right], q_{O F}$ is the specific overland flow $\left[\mathrm{m}^{2} \mathrm{~s}^{-1}\right], S$ the local slope and $\alpha\left[\mathrm{ks} \mathrm{s}^{0.4} \mathrm{~m}^{4.8}\right]$ is a surface erodibility parameter. The spatial distribution of $\alpha$ is given by the $\mathrm{C}$ (land cover and management) and $\mathrm{K}$ (soil erodibility) factors in the RUSLE equation [Renard et al., 1997], and its magnitude was calibrated with observed suspended sediment concentrations (SSCs) at the river basin outlet [Battista et al., 2020].

In the present work, we introduced additional localized sediment sources, i.e. landslides and incised areas, as potential hotspots of fine sediment production. We assumed that mobilization takes place by 
means of three new processes supported by these hotspots: sediment pickup from incised areas $(I)$, from the toe of landslides by action of the river flow $\left(L S_{R}\right)$ and from the body of landslides by action of hillslope overland flow $\left(L S_{H S}\right)$ (Fig. 2).

Sediment was assumed to be mobilized from the incised areas $I$ by action of the discharge in the inner gorges, when it exceeds a critical value. Such threshold behaviour represents the activation of debris flows and bank failures that supply sediment from hillslopes to the channel. Sediment was considered to be always available, when the critical bed shear stress in the river is exceeded.

The landslide processes $\left(L S_{R}\right.$ and $\left.L S_{H S}\right)$ were also assumed to have a threshold behaviour, in order to represent the episodic activation of the hillslope-channel coupling. In the light of the transport limited character of sediment flux on the hillslopes, we assumed that the sediment storage of landslides was also unlimited. We observe that in the basin there are landslides directly connected to the river network, which can be emptied by both $L S_{R}$ and $L S_{H S}$, and landslides disconnected from the river network, which are only emptied by $L S_{H S}$. The disconnected landslides deliver sediment to the channel only if the overland flow bed shear stress is sufficiently high along the flow path to the nearest channel cell, and therefore have a transient functional connectivity to the river network.

The sediment input from landslides and incised areas takes place when applied shear stresses exceed a threshold, with the same sediment transport formula applied to all three processes (Fig. 2):

$$
q_{s}=k \cdot\left(\theta-\theta_{c}\right)^{\mu}
$$

where $q_{s}\left[\mathrm{~m}^{2} / \mathrm{s}\right]$ is the specific sediment flux, $\theta$ is the dimensionless bed shear stress, $\theta_{c}$ the dimensionless critical bed shear stress and $k$ and $\mu$ are parameters that regulate the sediment flux. The parameters $k$ and $\mu$ depend on grain size, sediment mass density and the magnitude and non-linearity of the morphological response following the triggering of debris flows, bank collapses, and the activation of hillslope-channel coupling, and must be calibrated. Following a sensitivity analysis we assumed $\theta_{c}=0.05$ and constant in this study. The dimensionless bed shear stress $\theta$ is the key hydraulic factor that makes $q_{s}$ different on landslides, in channels and incised areas, despite the same parameters $k$ and $\mu$ in Eq. 2 (see Section 2.3).

[Figure 2 about here.]

The routing of sediment on the hillslopes and in the channels takes place in parallel from all sources. Overland flow $(O F)$ erosion and sediment transport takes place on all hillslope cells provided the hydrological forcing $q_{O F}>0$. Sediment is routed along the hillslope flow paths, it can be deposited if the transport capacity in Eq. 1 is exceeded, and is input into the river network once a channel cell is reached. Extra sediment is mobilized on the hillslopes on landslide surfaces $\left(L S_{H S}\right)$ when the overland flow shear stress exceeds the critical value $\theta_{c}$ (Eq. 2) and this sediment is input into the river network if transport capacity allows it. Rivers receive extra sediment input when they cross incised areas $(I)$ or the 
toes of landslides directly connected to the river network (process $L S_{R}$ ) and the streamflow bed shear stress exceeds $\theta_{c}$ (Eq. 2).

In the channels, fine sediment produced from all four sediment sources $\left(O F, L S_{H S}, L S_{R}, I\right)$ is routed as suspended load using an advection solution, neglecting diffusion and the possibility of sediment deposition. The sediment flux at any point in the river network consists of the sum of the four sediment fluxes at any given time step. The hypothesis of pure sediment advection neglects the recycling and mixing processes within the river network and is motivated by the efficient and supply-limited transport in the river network of the study basin (see Sect. 2.1). On the contrary, the possibility of deposition and re-mobilization of the eroded sediment on the hillslopes implies that the delivery of hillslope sediment by overland flow into the channels can be instantaneous during large rainfall events, or spread over long time periods when sediment undergoes many erosion-deposition cycles [see Battista et al., 2020].

Finally, we note that, because of the moderate geomorphic activity of the basin and the decadal-scale simulation horizon, we assumed that landslides and incised areas are fixed features in the basin and we did not consider the generation of new landslides or inner gorge sources at the timescales of our simulations.

\subsection{Gully competence parameter}

To compute the bed shear stress for hillslope and river cells, it is necessary to know the width of the flow confinement. In our study basin, the width for river cells was known from cross-section measurements provided by the Swiss Federal Office for the Environment (FOEN) along the river network. For hillslope cells, $O F$ erosion by surface runoff with rate $T_{c}$ takes place over the entire width of the cells $(\Delta x)$. However, landslide bodies can be heavily gullied, changing the active flow width of hillslope cells located on landslides. Therefore, a new parameter was needed to define the active cell width where erosion action and sediment transport take place.

We described the effect of overland flow channelization on the landslide body by assuming that the gullying of a landslide cell is represented by an equivalent width $w_{L S}$ of a gully that is always deep enough to contain all the overland flow on the cell $\left(w_{L S} \leq \Delta x\right)$. We introduced a parameter for gully competence $\lambda$, which represents this flow concentration:

$$
\lambda=\frac{\Delta x}{w_{L S}} .
$$

Low values of $\lambda\left(w_{L S} \approx \Delta x\right)$ mean that gullies on the landslide surface are wide and shallow, and therefore have a low competence for sediment transport, because flow is not concentrated and shear stress is low - this is a poorly gullied landslide (PGL). High values of $\lambda\left(w_{L S}<<\Delta x\right)$ represent a surface with narrow, deep and competent gullies, where the flow is concentrated and shear stress is large - this 
is a strongly gullied landslide (SGL).

It is expected that $\lambda$ has an effect on the partitioning of the sediment flux between landslides and incised areas. In our simulations we tested two end-member values $\lambda=1\left(w_{L S}=\Delta x\right)$ and $\lambda=100$ ( $w_{L S}=1 \mathrm{~m}, \Delta x=100 \mathrm{~m}$ ) as scenarios, and we present a possible way to estimate $\lambda$ from the statistical distribution of the surface roughness of landslide surfaces. To this end, we computed the standard deviation $\sigma_{z}$ of elevations from a high resolution $2 \mathrm{~m}$ LIDAR DEM in areas of $6 \times 6 \mathrm{~m}$ over the extent of each landslide. Given that the surface roughness on gully banks is higher than on the other parts of the landslide surface, high values of $\sigma_{z}$ in the frequency distribution indicate the presence of gullies on the surface. We selected an example of a poorly gullied landslide and a strongly gullied landslide in the Kleine Emme and we assumed their $\sigma_{z}$ frequency distributions to be representative of a $\lambda=1$ situation, and a $\lambda=100$ situation, respectively. To infer the $\lambda$ end-member value that better represents the gully development across the whole basin, we compared the $\sigma_{z}$ frequency distributions of the PGL and SGL to that of all landslide surfaces in the basin and chose the end-member that better matches the two distributions.

\subsection{Model calibration and simulations}

The hydrology-sediment model was set up for the period 2004-2016 with a spatial resolution of $\Delta x=100$ $\mathrm{m}$ and a time step of $\Delta t=1$ hour. The hydrological component was calibrated on streamflow measured at three stations in the basin for the same period, using as inputs hourly measurements of sunshine duration, air temperature, and precipitation measured at rain gauges and combined with the spatially distributed daily RhiresD dataset (MeteoSwiss). Overall, the model performed well in reproducing the hourly streamflow, e.g. reaching a correlation coefficient $r=0.84$ and model efficiency $\mathrm{ME}=0.69$ at the outlet [Battista et al., 2020].

The $\alpha$ parameter of the overland flow component in Eq. 1 was calibrated by considering only the $O F$ process and fitting the modelled and observed SSC-Q clouds of point and the frequency distribution of SSCs up to the $85^{\text {th }}$ quantile, i.e. ignoring the extremes. SSCs measurements are available at the outlet for the simulated period with a measurement frequency of two samples a week from the Swiss Federal Office for the Environment (FOEN). See Battista et al. [2020] for more details on the calibration of the OF process.

In this work, we kept the $\alpha$ parameter unchanged and calibrated the $k$ and $\mu$ parameters (Fig. 2 and Eq. 2) by maximizing the coefficient of determination $\mathrm{R}^{2}$ and the model efficiency ME in predicting all observed hourly suspended sediment loads, without any limitation on the quantiles. Given the two end-members for $\lambda$, calibration of $k$ and $\mu$ was performed twice: for $\lambda=1$ in SIM A (poorly gullied landslides), and for $\lambda=100$ in SIM B (strongly gullied landslides).

The simulated annual suspended sediment load was compared with two estimates of sediment load 
derived from observations, based on two different methods to extrapolate an annual load from the low temporal resolution SSC measurements available. The first (lower) estimate is based on yearly SSCQ rating curves fitted to each year of hourly observations, and used to infer the missing hourly SSCs $\left(\mathrm{Qs}_{M I N}^{O B S}=7.4110^{4} \mathrm{t} / \mathrm{y}\right)$, while the second (higher) estimate is based on an estimate of daily load from the observed SSCs only and gives more weight to the single SSC-Q observation pairs $\left(\mathrm{Qs}_{M A X}^{O B S}=2.8310^{5}\right.$ t/y, Hinderer et al. [2013], see BAFU [2016] for details).

Given the effect of $\lambda$ in regulating the sediment input from $L S_{H S}$ processes, SIM A and SIM B are expected to show different provenance of the sediment load at the outlet. Therefore, we performed a sensitivity analysis of $\lambda, k$ and $\mu$ parameters to compare the effect of each parameter on the sediment load provenance at the outlet. Taking SIM A as a reference, we varied $\lambda$ within the range $[1,100]$, and $k$ and $\mu$ within the ranges provided by their calibrated values for SIM A and SIM B.

\section{$2.5 \quad{ }^{10}$ Be concentration data}

To corroborate the estimate of $\lambda$ obtained in Sect. 2.3, we applied sediment tracing in the model by using measurements of ${ }^{10} \mathrm{Be}$ concentrations available across the basin in different morphologies and at the outlet.

Because ${ }^{10} \mathrm{Be}$ concentrations on the surface are inversely proportional to the long-term erosion rates, they are expected to label the sediments mobilized by different processes with a different concentration. From data of in-situ produced CRN rates available from the literature in the basin [Clapuyt et al., 2019, Van den Berg and Schlunegger, 2012, Norton et al., 2008, Casagrande, 2014], we selected samples on landslide surfaces, in headwater channels, and in a subbasin including incised areas, to derive a concentration representative of each sediment production process simulated in the model. The details of the computation of the representative concentrations are reported in the Supporting Information. The location of the samples is shown in Fig. 1 and the resulting ${ }^{10}$ Be concentrations associated with the production processes are reported in Table 1. By assigning these concentrations to the corresponding modelled sediment fluxes at the outlet, we were able to derive a time series of ${ }^{10} \mathrm{Be}$ concentration at the outlet for SIM A and SIM B.

[Table 1 about here.]

We analysed the frequency distributions of simulated ${ }^{10} \mathrm{Be}$ concentrations in the suspended sediment under SIM A and SIM B to highlight how differences in sediment production sources and their activation will impact the time-dependent mixing of sediment at the outlet. We compared these distributions with a single river bed ${ }^{10} \mathrm{Be}$ sediment sample taken close to the outlet by Wittmann et al. [2007], to assess which of the two simulations better represents erosion processes in the study basin.

Finally, we discuss the implications of the modelled temporal fluctuations of ${ }^{10} \mathrm{Be}$ concentration for 
the sampling of river sediment that is representative of long term denudation rates. To this end, we also used the model results to investigate how the sampling location in the cross section might affect the representative value of the sediment transported in the river at that location. In particular, we computed the variability of the modelled ${ }^{10} \mathrm{Be}$ concentration expected in river bed samples taken at different elevations on the river bed. To do so, we first identified the water depth that fully covers the mobile part of the bed based on the outlet cross section profile provided by FOEN (the banks of the channel are protected and fixed). Second, from this water depth we derived the range of discharges during which sampling is possible, given the water level h-Q relationship at the outlet cross section (also provided by FOEN), and we computed the water depths corresponding to the $5^{\text {th }}, 25^{\text {th }}, 50^{\text {th }}$ and $75^{\text {th }}$ percentiles of this range of discharge. Finally, we filtered the modelled ${ }^{10} \mathrm{Be}$ concentration distribution with the modelled discharges that reach or exceed these water depths. These are the concentrations potentially deposited by the flow on the river bed above the corresponding water levels $\left(\mathrm{h}_{5}, \mathrm{~h}_{25}, \mathrm{~h}_{50}\right.$ and $\left.h_{75}\right)$. The described approach assumed that deposition is independent of the grain-size and flow conditions.

\section{Results}

\subsection{Sediment sources and simulated SSCs}

The results of the two calibrated simulations $\operatorname{SIM} \mathrm{A}(\lambda=1)$ and $\operatorname{SIM} \mathrm{B}(\lambda=100)$ are presented in Fig. 3 in terms of modelled SSCs against discharge. In Fig. 3 we associated a color to each of the sediment production processes and then filled each Q-SSC dot by mixing these colors proportionally to the relative contribution of each source. Therefore, the color coding indicates the process, or the combination of processes, generating each hourly SSC. The overland flow process $O F$ is the dominant sediment production process at lower discharges, generating the lower modelled SSCs (red markers). At higher flows, the threshold processes $I$ and $L S_{H S}$ (blue and green markers) become the dominant sediment production processes. The highest SSCs are generated in SIM A by sediment pickup from incised areas $(I)$, and in SIM B from the body of landslides $\left(L S_{H S}\right)$, and this is reflected in the composition of the yearly load reported in Table 2 , where $I$ contributes $81 \%$ of the total sediment mass in SIM A and $L S_{H S}$ contributes $98 \%$ of the total sediment mass in SIM B. This result indicates that the different parameterization of SIM A and B has the effect to redistribute the sediment provenance between these two dominant sources. The calibrated parameters of the hydrology-sediment model for both simulations and the modelled annual sediment loads are listed in Table 2.

The model performance is presented in Table 3 by evaluating the fit of observed and modelled hourly sediment flux $\mathrm{Q}_{s}$, SSC variability, and annual sediment yield. It is interesting to note that the two calibrated simulations produced almost equally good values of the goodness-of-fit metrics. In both 
simulations, the coefficient of determination $\mathrm{R}^{2}$ and the model efficiency ME of the hourly loads $\mathrm{Q}_{s}$ are rather low in terms of their absolute values [Moriasi et al., 2007], however, considering the simplified representation of the suspended sediment transport in the channels and that similar models show $\mathrm{R}^{2}$ of about 0.7 and ME between 0.5 and 0.9 for daily or monthly temporal resolutions [Francipane et al., 2012, Betrie et al., 2011, Tsuruta et al., 2018], the results can be considered relatively good in the framework of this type of models. The percentage of SSCs falling within the $[5,95]^{\text {th }}$ and $[25,75]^{\text {th }}$ percentiles of observations quantifies the fit between the modelled and observed SSC-Q relation and its scatter, and indicates that both simulations almost perfectly captured the observed variability. The comparison of the modelled mean annual sediment loads with the higher estimate $\mathrm{Q}_{s} \underset{M A X}{O B S}$ from observations [Hinderer et al., 2013] gives very good results, with slight underestimation (-22\%) by SIM A and slight overestimation $(+33 \%)$ by SIM B.

The almost equal performance of the two simulations suggests that a good fit with the observations may be achieved by very different combinations of sediment source activation and that it may not be possible to identify the dominant sediment sources based on the sediment dynamics properties only. This limitation could be in part related to the low temporal resolution of the SSC observations in the study basin, which does not allow to fully characterize the SSC-Q relation, and therefore to discriminate between the two solutions. However, this quality of SSC data is typical in many monitored catchments and as a consequence the physical meaningfulness of the parameters, especially $\lambda$, needs to be validated with an independent analysis.

[Figure 3 about here.]

[Table 2 about here.]

[Table 3 about here.]

\subsection{Sensitivity analysis}

The results of the previous section indicate how the different parameterisations of SIM A and B redistribute the provenance of the outlet sediments among the different sources. In this section we investigate the role of each parameter $\lambda, \mu$ and $k$ in determining the distribution of sediment provenance. To do so, we carried out a sensitivity analysis of SIM A to these parameters in the ranges defined by the calibrated values of SIM A and B (see Table 2).

The fraction of the mean yearly suspended sediment load generated by each sediment mobilization process as a function of the studied parameters is shown in Fig. 4. On the left side of the $\mathrm{x}$-axis of the plots, $\lambda, \mu$ and $k$ have the values of calibrated SIM A, and on the right side the values of calibrated SIM 
B. The lines are the fractions of yearly load in a simulation that has the same parameters as SIM A, except for the parameter on the x-axis, and the symbols (square, triangle and diamonds) indicate the partitioning of sediment load in SIM B.

Fig. 4 shows that $\mu$ and $k$ mainly affect the ratio between threshold $\left(I, L S_{R}\right.$ and $\left.L S_{H S}\right)$ and continuous $(O F)$ processes, while $\lambda$ strongly affects the hillslope $\left(L S_{H S}\right.$ and $\left.O F\right)$ to channel $(I$ and $\left.L S_{R}\right)$ process ratio, by increasing the $L S_{H S}$ contribution as it grows. We observe that SIM A with $\lambda=100$ closely captures the SIM B yearly load partitioning (square, triangle and diamonds) even if the $\mu$ and $k$ parameters have not been changed (Fig. 4a). On the contrary, the composition achieved by SIM A with $\mu$ and $k$ of SIM B is very different from SIM B composition. This result indicates that among the three main model parameters, $\lambda$ has a dominant role in determining the sediment load composition at the basin outlet. In other words, it is the key parameter that redistributes sediment provenance towards incision areas, in the poorly gullied case (SIM A), and landslide surfaces, in the strongly gullied case (SIM B).

[Figure 4 about here.]

\subsection{Landslide surface roughness to quantify gully competence}

The first independent validation of the two end-member simulations SIM A and SIM B is by estimating the gully competence parameter $\lambda$ directly from topographic analysis of landslide surfaces. The surface roughness of two selected landslide surfaces measured by the local standard deviation of the topographic height $\sigma_{z}$ is shown in Fig. 5. The spatial maps clearly show that the poorly gullied landslide (PGL, top) has less rill and gully formation and a much lower roughness measured by lower mean $\sigma_{z}$, variance and more skewed distribution, while the strongly gullied landslide (SGL, bottom) has very significant and deep gullies distributed over the surface and a much higher roughness measured by higher $\sigma_{z}$, variance, and a less skewed distribution.

To assess if the entire basin of the Kleine Emme is more like PGL or SGL, we computed the frequency distribution of $\sigma_{z}$ and its basic statistics over all landslide surfaces in the catchment based on the $2 \mathrm{~m}$ resolution Lidar DEM. Our hypothesis is that if a better overlap exists for PGL, the simulation SIM A $(\lambda=1)$ would be a more accurate description of the sediment processes in the basin, while if a better overlap exists for SGL, then simulation SIM B $(\lambda=100)$ would the better choice. The frequency distribution of $\sigma_{z}$ for all landslides is shown in Fig. 5g, and it is clearly more similar to the PGL $\sigma_{z}$ distribution (D Kolmogorov-Smirnov $(\mathrm{PGL})=0.22$, D Kolmogorov-Smirnov(SGL)=0.58). We conclude that landslide surfaces in the Kleine Emme have weakly developed gullies and SIM A is a better endmember parameterisation, giving more weight to the role of incised rivers in inner gorges as a sediment source. 
We note that the surface roughness is, however, high in other steep regions too, like the landslide scarp. This adds spuriously high $\sigma_{z}$ in the frequency distribution of the PGL and of the global distribution, while the SGL does not present such features. Removing the spurious $\sigma_{z}$ would reduce the mean $\sigma_{z}$ and the skewness of the PGL and of the global $\sigma_{z}$ distribution, thus differentiating them even more from the SGL, and is therefore not expected to change the results of this comparison.

[Figure 5 about here.]

\section{4 ${ }^{10} \mathrm{Be}$ as a sediment tracer}

The second independent validation of the two end-member simulations SIM A and SIM B is by using ${ }^{10} \mathrm{Be}$ concentrations as a sediment tracer. Time series of modelled ${ }^{10} \mathrm{Be}$ concentrations in the suspended sediment in transport have been derived by associating the representative concentration of each sediment production process to the corresponding sediment flux at the outlet and computing an average ${ }^{10} \mathrm{Be}$ concentration. They are presented in Fig. 6a for SIM A and 6c for SIM B for one representative year. As it is expected for basins dominated by mass movements, the ${ }^{10}$ Be tracer shows strong temporal fluctuations driven by the flow rate. Higher flow rates activate the threshold processes in $L S_{R}, L S_{H S}$ and $I$, generating pulses of lower ${ }^{10} \mathrm{Be}$ concentrations. The amplitude of the fluctuations is greater in SIM A because of the lower ${ }^{10} \mathrm{Be}$ concentration in the incised areas compared to landslides. The frequency distribution of ${ }^{10} \mathrm{Be}$ concentrations in the entire simulation period (Fig. $6 \mathrm{~b}$ and $6 \mathrm{~d}$ ) is bimodal in SIM A, with a peak at the highest concentrations representing the overland flow erosion process, and at the lowest concentrations, generated by the sediment mobilized from the incised areas and the landslide toes. The clustering of concentrations around two frequency peaks in SIM A, compared to the single peak distribution of SIM B, suggests that the hydrologic conditions that mobilize the sediments from incised areas and from the toes of the landslides are more similar to each other than those that mobilize sediments from the body of landslides. This can be explained by more variable hydrologic (surface runoff) conditions on the hillslopes than in the channel.

In Fig. $6 \mathrm{~b}$ and $6 \mathrm{~d}$ the modelled ${ }^{10} \mathrm{Be}$ concentrations in suspended sediment are compared to a single river bed sample concentration by Wittmann et al. [2007]. The observed ${ }^{10}$ Be concentration at the outlet from Wittmann et al. [2007] falls at the low concentration end of SIM A frequency distribution, but outside of the range of SIM B simulated frequency distribution. This supports the hypothesis that SIM A is more likely to be compatible with the ${ }^{10}$ Be observation, and therefore indicates low values of $\lambda$, in the vicinity of 1 , as a more representative parameterization of the sediment production and transport processes. The simulated distribution of ${ }^{10} \mathrm{Be}$ concentrations compared to the observation would suggest that the sample by Wittmann et al. [2007] is representative of extreme flow conditions. However, we will discuss in Sect. 4.2 the difficulties associated with such a comparison and its interpretation. 
Finally, we explore how well a sediment sample taken on the river bed represents the sediment transported in the river at that location, depending on the sampling location in the cross section. We show in Fig. 7 that if the suspended sediment was partially deposited on the river bed as a function of the inundation frequency, there would be a gradient in river bed sediment ${ }^{10} \mathrm{Be}$ concentration with increasing height above the thalweg. Both in SIM A and SIM B, the mean concentration on the river bed decreases with the height, as higher parts of the river bed and bank are only inundated by larger discharges, which are likely to carry high sediment loads from incision areas and landslides with lower ${ }^{10} \mathrm{Be}$ concentrations. The variability of concentrations in sediment deposited on the bed decreases with river bed height in SIM A, while it increases in SIM B. This is indicative of the fact that a wider range of discharges is responsible for sediment mobilization from the localized sources in SIM B, compared to SIM A.

\section{Discussion}

\subsection{Importance of localized production processes in mountain basins}

The implementation of sediment mobilization from localized high sediment production areas with a threshold activation and a strongly non-linear transport rate in a hydrology-sediment model allowed us to reproduce the full range of observed SSCs, the variability in the observed SSC-Q relation, and the annual sediment load at the outlet of the Kleine Emme catchment (Fig. 3 and Table 3). This represents a substantial improvement in the model performance compared to only including diffuse overland flow erosion in Battista et al. [2020], which resulted in an underestimation of the high sediment concentration pulses and the total sediment yield. This raises the possibility that many other distributed physicallybased erosion and sediment transport models based on overland flow alone are probably not suitable for applications in mountain areas, where mass wasting and localized sources dominate the sediment production.

Some evidence for this can be found in the literature. WATEM/SEDEM and RUSLE are based on overland flow erosion and have been found to perform poorly in mountain catchments [Van Rompaey et al., 2005, Borrelli et al., 2014, 2018]. Already in the early work of Benda and Dunne [1997], stochastic sediment input from landslides and debris flows was proposed to be an important part of the sediment budget in river network models. de Vente et al. [2006] applied a suspended sediment yield semiquantitative model to 40 catchments including mountainous environments, and found that the model performance substantially increased when the presence of landslides was accounted for. Several authors 
have indeed proposed modelling frameworks to simulate the dynamics of such localized sources in mountain environments with different approaches and degrees of complexity [e.g. Wichmann et al., 2009, Bennett et al., 2014, Taccone et al., 2018].

The approach presented here allows, furthermore, to track the sediment produced by the different sources in space and time, and therefore to understand when and why certain sources dominate in the model. For example, the dominant sediment production from incised areas in SIM A is the result of a channel-process dominated system, while SIM B represents a hillslope-process dominated system because most of the sediment load is sourced from the landslide bodies. While the sediment mobilization Eq. 2 in our model is the same for all three localized sediment production processes, the gully competence parameter $\lambda$ on landslides allows to differentiate between the frequency of activation of hillslope and channel processes. In SIM A and SIM B we have considered the two extreme values of $\lambda$ and, coherently, we obtained respectively very low and very high ratios of hillslope to channel process contributions. We conclude that a more realistic $\lambda$ for the study basin would probably be an intermediate value between the two end members, and with our analysis we can estimate whether this value should lie close to $\lambda=1$ or $\lambda=100$.

Poor gully development on landslide bodies and the comparison of modelled time series of ${ }^{10} \mathrm{Be}$ concentrations with measurements, suggest that SIM A is more representative of the Kleine Emme basin than SIM B (see Fig. 5 and Fig. 6). Therefore, low values of $\lambda$ are more suitable to parameterize the study catchment, suggesting that channel processes of sediment production are possibly more important than hillslope processes in this catchment. This result is consistent with field observations by Schwab et al. [2008], who proposed that in the Kleine Emme the connectivity between landslides on the hillslopes and the river network only takes place occasionally by activation of debris and earth flows. Clapuyt et al. [2019] also argued that this coupling is switched on only rarely and for short periods of time and therefore the contribution of hillslope-generated sediments to the annual sediment load is negligible most of the time. The hypothesis of dominant channel sediment production processes in the Kleine Emme basin is supported by qualitative geomorphological observations, such as the presence of river cut terraces and the lack of significant main river adjustment at the confluence of small tributaries. Finally, the presence of multiple gorges with upstream migrating knickpoints also suggests that they act as a significant source of sediment [Schwab et al., 2008, Schlunegger and Schneider, 2005, Van den Berg and Schlunegger, 2012, Dürst Stucki et al., 2012].

\subsection{Implications for the use of CRN data and for provenance studies}

The parallel routing of mobilized sediment from different sources to the outlet allows us to produce a transient mixing of sediment that is driven by the space-time variable hydrological regime, i.e. surface runoff. We used ${ }^{10} \mathrm{Be}$ as a sediment tracer in this regards to simulate time series of ${ }^{10}$ Be concentration 
at the outlet (Fig. 6). ${ }^{10}$ Be concentrations can be used to derive denudation rates. However, we caution against the use of such modelled concentrations to derive catchment-wide denudation rates for three main reasons: (1) $\mathrm{CRN}$-derived denudation rates are inferred from riverbed sediment samples, while we do not simulate a river bed sediment storage and only simulate the concentration of fine sediment in transport. This also implies that fluvial mixing is not simulated, while this has been demonstrated to be an important factor to smooth out temporal fluctuations of CRN concentrations [Yanites et al., 2009]. (2) Our model is suitable for decadal time scales only, and does not account for the formation of new landslides, activation and extension of new inner gorges, knickpoint migration, etc., on longer time scales. On the contrary, denudation rates derived from CRN concentrations integrate time scales of 100$10^{5}$ years and therefore also include these processes. (3) Representative ${ }^{10} \mathrm{Be}$ concentrations attributed to the sediment production processes in our model (see Table 1) as a tracer are imperfect, as they are derived from a limited number of samples non-uniformly distributed in space (Fig. 1). Moreover, in the interpolation of the sample concentrations we neglected the dependence of ${ }^{10} \mathrm{Be}$ concentration on elevation and grain size [Lukens et al., 2016, Van Dongen et al., 2019] (see Supplementary Information). These limitations introduce an uncertainty in the modelled ${ }^{10} \mathrm{Be}$ concentrations at the outlet.

Nevertheless, compared to models specifically developed for CRN dynamics at $10^{5}-10^{6}$ years temporal scales [Niemi et al., 2005, Yanites et al., 2009], our model includes explicit spatial dependencies along flowpaths and is characterized by a high temporal resolution (hourly). This can provide insights into the short term dynamics of CRNs and help to guide the collection of samples representative of long-term catchment-average denudation rates in mass-movement dominated basins.

In the first place, results like those in Fig. 6 can be used to identify the most suitable hydrological conditions for sampling. They allow one to discriminate between hydrological conditions leading to a suspended sediment load dominated by one single process, and those producing instead a mix of sediment sources. Samples for CRN concentration measurements are usually taken from river bed sediment, however in some conditions the provenance of the suspended sediment load can be taken as a proxy for the variability in the fine fraction of riverbed sediments. This is the case for example in the Kleine Emme, where the sediment storage capacity of the river bed is estimated to be small and the residence time of the fine sediment in the basin to be short. Here, we expect the actual smearing effect [Yanites et al., 2009] of hillslope inputs by fluvial mixing to be rather small and, in the period following a large flood, the streambed sediment to be composed mostly of localized source sediment. A sample of such sediment is neither representative of long-term erosion rates, as it is influenced by an exceptional event, nor of catchment-averaged erosion rates, as some regions of the basin are over-represented. Therefore, the two main assumptions at the basis of denudation rate estimates from CRN concentration fail [von Blanckenburg, 2005].

Additional useful information for CRN sampling is provided by the correlation between suspended 
sediment ${ }^{10} \mathrm{Be}$ concentrations and river bed sampling height above the thalweg. Fig. 7 suggests that samples taken higher up on the river bank are likely to be over-representative of localized sediment sources activated by higher flows, therefore it is important to sample closer to the low flow channel to get a more integrated sediment source signal. At the same time, Fig. 7 also indicates that the location of sampling matters especially in basins where localized sources of sediments produce a clearly distinct signal for a given range of discharges (SIM A). In these basins, because the variability of potentially deposited concentration decreases with sampling elevation, the probability of observing concentrations that are over-representative of localized sediment sources at the higher locations, is higher compared to SIM B.

To summarize, two practical suggestions can be drawn to guide the sampling of ${ }^{10}$ Be concentrations representative of long-term catchment-average denudation rates in mass-movement dominated basins: (1) preferring sampling during low flow conditions, while avoiding it during and immediately after highflow events; (2) avoiding sampling from high-flow deposits by sampling as close as possible to the low flow channel.

Our modelling results predicted a wide distribution of possible ${ }^{10} \mathrm{Be}$ concentrations at the catchment outlet, in which the observation made by Wittmann et al. [2007] are exceptionally low. This would intuitively suggest that their sample is representative of an extreme flow event and that the actual catchment integrated erosion rate is much lower. However, there are several issues involved with such a comparison. The first issue is the uncertainty in the modelled ${ }^{10} \mathrm{Be}$ concentrations at the outlet, due to the imperfect estimate of the representative ${ }^{10}$ Be concentration in the sediment sources (Table 1). The second is that Wittmann et al. [2007] sampled on the river bed and we are comparing their data with suspended sediments in transport. This implies that the observed grain size is likely to be coarser than the simulated one, and this might introduce a bias towards lower concentrations in the measurements.

Finally, we argue that the approach presented here is useful in combination with fingerprinting methods to complement sediment provenance studies, thus increasing the understanding of the sediment dynamics in river basins. On the one hand, observations of sediment provenance estimated by fingerprinting methods are needed to calibrate the model, as we have proposed by comparing the simulation results with a single measurement of ${ }^{10} \mathrm{Be}$ concentration. Time series of observations of tracers that label the different sediment sources, such as those derived by Navratil et al. [2012], Cooper et al. [2015], Uber et al. [2019], would substantially improve the accuracy of such calibration. On the other hand, the modelling concept can be used to generalize the observations of fingerprinting studies, which allow to reconstruct the sediment provenance only at a limited number of locations and for a limited period of time determined by the availability of field observations. The combination of such datasets with the application of our model would allow to investigate the climatic forcings that produce specific sediment load compositions, as well as to extrapolate the information about sediment provenance to other hy- 
drological conditions and locations across the basin, besides the observed ones. At the same time, the transient routing produced by the model may also provide a physically-based concept to support the choice of statistical mixing models used in fingerprinting methods [e.g Evrard et al., 2011, Blake et al., 2018].

\subsection{Limitations and further developments}

We discuss in the following three main limitations of the model.

The first limitation is the confined model structure. High accuracy was used for the hydrological physical process representation, leading to space-time dependent surface runoff generation, and in identifying possible sediment sources by geomorphological mapping. On the contrary, simplified representations were chosen for overland flow erosion and threshold sediment mobilization from landslides and incised areas. The latter have as few parameters as possible while remaining physically meaningful, to avoid model over-parameterisation with only a single station with SSC observations to compare with. We recognise that other erosion models may use much more complex formulations for erosion and sediment transport, and these could be included in the future, especially for applications where more data are available. Additionally, we focus on bulk fine sediment produced in the catchment and transported in suspension only, because this is the main mode of sediment transport contribution to total yield in many alpine environments [Turowski et al., 2010]. Including multiple grain sizes, processes of grain size fining during transport and the interaction between bedload and suspended load would provide a significant improvement and expand the application possibilities.

Model calibration is a second limitation. We performed a manual calibration of the few parameters that needed to be defined, e.g. $\alpha, \theta, k$ and $\mu$, by varying a single parameter at a time. We did not vary them simultaneously with an automatic calibration procedure because of computational limitations. In our end-member based analysis, such calibration would allow a better tuning of the parameters and therefore of the contribution of the different processes to the outlet sediment load. However, it is not expected to significantly alter the results of our analysis, as we have shown that $O F$ is only responsible for low SSCs and $\lambda$ has a dominant role on the sediment contribution compared to $\mu$ and $k$. The added value of an automatic calibration would be to easily identify the intermediate values of $\lambda$ and corresponding combinations of parameters that equally match the observed SSCs, i.e. several sediment load compositions that represent plausible balances among the sediment production processes in the study basin. To solve this non-uniqueness problem, additional sediment-specific tracing data from the sources of sediments in a basin would be needed, such as additional measurements of tracers at the outlet repeated in time. For example, meteoric ${ }^{10} \mathrm{Be}$ has also been showed to be an effective tracer of sediment production processes within a catchment, with the advantage of being quicker and cheaper than cosmogenic ${ }^{10} \mathrm{Be}$ [Reusser and Bierman, 2010]. In order to further constrain the problem, process- 
labeling tracers like cosmogenic and meteoric ${ }^{10} \mathrm{Be}$ could be associated with tracers adding information on the soil depth of sediment provenance (e.g. ${ }^{137} \mathrm{Cs}$ ) and the travel time of sediments from the source to the outlet (e.g. ${ }^{7} \mathrm{Be} /{ }^{210} \mathrm{~Pb}_{x s}$ ) [Evrard et al., 2016]. In this respect, the modelling framework also offers a possibility to propagate uncertainty, i.e. to simulate sediment fluxes with many realisations of a stochastic climate and parameter values from pre-defined probability distributions, thereby explicitly quantifying the uncertainty in the SSC predictions and partitioning it to climatic, model parameter, and tracer sources.

Finally, in further work, the role of the spatial distribution of $\lambda$ and its variability in time could be explored. In this work we chose to use a constant value, to explore its role in basin scale modelling. However, Clapuyt et al. [2019] showed that episodic hillslope-channel coupling in specific landslide areas in the Kleine Emme basin are key in determining the seasonal sediment load contributions, even if often negligible at the annual scale. This suggests that a better representation of the hillslope-channel balance in the Kleine Emme could be obtained by using a temporally variable $\lambda$. At the same time, $\lambda$ can be expected to also be spatially variable because landslide surfaces have diffferent gradients, morphologies, soils, etc. This is also indicated by the variance of the distribution of surface roughness across all landslides in the study area of this work. An example is the difference between the northwestern region of the basin (Fontanne subcatchment) characterized by narrow and deeply incised valleys and the southeastern region (Entle subcatchment), dominated by wide valley and major instabilities disconnected from the river network [Van den Berg and Schlunegger, 2012, Norton et al., 2008, Schlunegger and Schneider, 2005]. In a further development of the model, the gully competence parameter on landslides should be adapted to represent a higher complexity and thus simulate more general relations between the size and morphologies of landslide bodies, and the different degrees of hillslope-channel connectivity.

\section{Conclusions}

We presented a hydrology-sediment modelling framework based on the model Topkapi-ETH combined with geomorphic mapping that accounts for localized processes of suspended sediment mobilization, in an application to the pre-Alpine Kleine Emme basin in Switzerland. We introduced sediment mobilization from landsliding areas and incised river gorges, by activation of threshold processes such as erosion of banks and landslide toes, in addition to overland flow erosion. Fine sediment is routed along topographically-driven pathways in parallel from all sources to the outlet. This allows us to reproduce the suspended sediment load composition and its temporal dynamics, including ${ }^{10} \mathrm{Be}$ concentrations as a sediment tracer. The main outcomes of the work are as follows:

(1) The modelling framework with additional concentrated sediment sources from landslides and incised areas allowed us to improve the simulation of observed suspended sediment concentrations and 
annual sediment load at the outlet, compared to modelling overland flow erosion alone. Such localized sources activated only episodically by surface runoff on hillslopes or high discharge in rivers are very important in the sediment budget of the studied basin.

(2) We quantified two end-members of modelled sediment provenance that could explain the observed SSCs at the outlet of the basin: channel-dominant processes from incised areas, and hillslope-dominant processes from landslide surfaces. In our model, the competition between these two processes is a function of the parameter of gully competence, which adjusts the hillslope sediment production rate on landslide surfaces.

(3) By independent validation of the model with topographic analysis of surface roughness and sediment tracing with ${ }^{10} \mathrm{Be}$ concentrations, it was possible to infer the dominant sediment production processes in the basin. In the study case, we found that the end-member assuming poor landslide surface gullying and giving more weight to channel processes is more consistent with observations.

(4) The modelled temporal dynamics of sediment load composition provides useful information for guiding sediment sampling for CRN basin denudation rate estimates. Such information can be summarized into the following suggestions: (a) preferring sampling during low flow conditions, while avoiding it during and immediately after high-flow events; (b) avoiding sampling from high-flow deposits by sampling as close as possible to the low flow channel.

This research shows that inputs of localized rich sediment sources activated episodically by hydrological processes can be very important for sediment budgets in mountain basins and should be taken into account when modelling their sediment dynamics. It also shows that transient mixing of sediment from these sources by hydrologically driven runoff generation is to some degree predictable with numerical models. Finally, the proposed framework can be used to generalize the information of sediment apportionment derived by fingerprinting measurements, by linking it to climatic variables and hydrological conditions.

\section{Acknowledgments}

This work was founded by the DAFNE project, an Horizon 2020 programme WATER 2015 of the European Union, GA no. 690268. We thank the Swiss Federal Office of Topography for providing the SwissAlti3d DEM (https://shop.swisstopo.admin.ch/en/products/height_models/alti3D) and the GeoCover V2 map (https://shop.swisstopo.admin.ch/en/products/maps/geology/GC_VECTOR), and the Swiss Federal Office for the Environment for providing the cross section measurements. 


\section{References}

BAFU. Hydrologisches Jahrbuch der Schweiz 2010. Technical report, Swiss Federal Office for the Environment, 2016.

A. Bathurst and J. C. Burton. Physically based modelling of shallow landslide sediment yield at a catchment scale. Environmental geology, 35(August):89-99, 1998.

G. Battista, P. Molnar, and P. Burlando. Modelling impacts of spatially variable erosion drivers on suspended sediment dynamics. Earth Surface Dynamics, 8(3):619-635, jul 2020. ISSN 2196-632X. doi: 10.5194/esurf-8-619-2020. URL https://esurf . copernicus.org/articles/8/619/2020/.

L. Benda and T. Dunne. Stochastic forcing of sediment routing and storage in channel network in channel networks. Water Resources Research, 33(12):2865-2880, 1997. ISSN 0340-7594.

G. L. Bennett, P. Molnar, B. W. McArdell, and P. Burlando. A probabilistic sediment cascade model of sediment transfer in the Illgraben. Water Resources Research, 50(2):1225-1244, feb 2014. ISSN 00431397. doi: 10.1002/2013WR013806. URL http://doi.wiley.com/10.1002/2013WR013806.

G. D. Betrie, Y. A. Mohamed, A. Van Griensven, and R. Srinivasan. Sediment management modelling in the Blue Nile Basin using SWAT model. Hydrology and Earth System Sciences, 15(3):807-818, 2011. ISSN 10275606. doi: 10.5194/hess-15-807-2011.

W. H. Blake, P. Boeckx, B. C. Stock, H. G. Smith, S. Bodé, H. R. Upadhayay, L. Gaspar, R. Goddard, A. T. Lennard, I. Lizaga, D. A. Lobb, P. N. Owens, E. L. Petticrew, Z. Z. A. Kuzyk, B. D. Gari, L. Munishi, K. Mtei, A. Nebiyu, L. Mabit, A. Navas, and B. X. Semmens. A deconvolutional Bayesian mixing model approach for river basin sediment source apportionment. Scientific Reports, 8(1):1-12, 2018. ISSN 20452322. doi: 10.1038/s41598-018-30905-9.

P. Borrelli, M. Märker, P. Panagos, and B. Schütt. Modeling soil erosion and river sediment yield for an intermountain drainage basin of the Central Apennines, Italy. Catena, 114:45-58, 2014. ISSN 03418162. doi: 10.1016/j.catena.2013.10.007. URL http://dx.doi.org/10.1016/j.catena.2013. 10.007 .

P. Borrelli, K. Van Oost, K. Meusburger, C. Alewell, E. Lugato, and P. Panagos. A step towards a holistic assessment of soil degradation in Europe: Coupling on-site erosion with sediment transfer and carbon fluxes. Environmental Research, 161(May 2017):291-298, 2018. ISSN 10960953. doi: 10.1016/j.envres.2017.11.009. URL https://doi.org/10.1016/j.envres. 2017.11.009.

L. J. Bracken, L. Turnbull, J. Wainwright, and P. Bogaart. Sediment connectivity: A framework for understanding sediment transfer at multiple scales. Earth Surface Processes and Landforms, 40(2): 177-188, 2015. ISSN 10969837. doi: 10.1002/esp.3635. 
J. Casagrande. What controls erosion? Quantitative estimation of erosion using 10Be in Flühli/LU (Switzerland). Technical report, University of Bern, Bern, 2014.

F. Clapuyt, V. Vanacker, F. Schlunegger, M. Christl, and K. Van Oost. Spatio-temporal dynamics of sediment transfer systems in landslide-prone alpine catchments. Solid Earth, pages 1-22, 2019. doi: $10.5194 /$ se-2018-139

R. J. Cooper, T. Krueger, K. M. Hiscock, and B. G. Rawlins. High-temporal resolution fluvial sediment source fingerprinting with uncertainty: A Bayesian approach. Earth Surface Processes and Landforms, 40(1):78-92, 2015. ISSN 10969837. doi: 10.1002/esp.3621.

T. J. Coulthard, J. C. Neal, P. D. Bates, J. Ramirez, G. A. de Almeida, and G. R. Hancock. Integrating the LISFLOOD-FP 2D hydrodynamic model with the CAESAR model: Implications for modelling landscape evolution. Earth Surface Processes and Landforms, 38(15):1897-1906, 2013. ISSN 10969837. doi: $10.1002 /$ esp.3478.

F. Cruz Nunes, R. Delunel, F. Schlunegger, N. Akçar, and P. W. Kubik. Bedrock bedding, landsliding and erosional budgets in the Central European Alps. Terra Nova, 27(5):370-378, 2015. ISSN 13653121. doi: $10.1111 /$ ter.12169.

J. de Vente, J. Poesen, P. Bazzoffi, A. Van Rompaey, and G. Verstraeten. Predicting catchment sediment yield in mediterranean environments: The importance of sediment sources and connectivity in Italian drainage basins. Earth Surface Processes and Landforms, 31(8):1017-1034, 2006. ISSN 01979337. doi: 10.1002/esp.1305.

R. Delunel, P. A. van der Beek, D. L. Bourlès, J. Carcaillet, and F. Schlunegger. Transient sediment supply in a high-altitude Alpine environment evidenced through a 10Be budget of the Etages catchment (French Western Alps). Earth Surface Processes and Landforms, 39(7):890-899, 2014. ISSN 10969837. doi: 10.1002/esp.3494.

K. D’Haen, B. Dusar, G. Verstraeten, P. Degryse, and H. De Brue. A sediment fingerprinting approach to understand the geomorphic coupling in an eastern Mediterranean mountainous river catchment. Geomorphology, 197:64-75, 2013. ISSN 0169555X. doi: 10.1016/j.geomorph.2013.04.038. URL http: //dx.doi.org/10.1016/j.geomorph.2013.04.038.

C. O. Doten, L. C. Bowling, J. S. Lanini, E. P. Maurer, and D. P. Lettenmaier. A spatially distributed model for the dynamic prediction of sediment erosion and transport in mountainous forested watersheds. Water Resources Research, 42(4):1-15, 2006. ISSN 00431397. doi: 10.1029/2004WR003829.

M. Dürst Stucki, F. Schlunegger, F. Christener, J. C. Otto, and J. Götz. Deepening of inner gorges through subglacial meltwater - An example from the UNESCO Entlebuch area, Switzerland. Ge- 
omorphology, 139-140:506-517, 2012. ISSN 0169555X. doi: 10.1016/j.geomorph.2011.11.016. URL http://dx.doi.org/10.1016/j.geomorph.2011.11.016.

O. Evrard, O. Navratil, S. Ayrault, M. Ahmadi, J. Némery, C. Legout, I. Lefèvre, A. Poirel, P. Bonté, and M. Esteves. Combining suspended sediment monitoring and fingerprinting to determine the spatial origin of fine sediment in a mountainous river catchment. Earth Surface Processes and Landforms, 36 (8):1072-1089, 2011. ISSN 10969837. doi: 10.1002/esp.2133.

O. Evrard, J. P. Laceby, S. Huon, I. Lefèvre, O. Sengtaheuanghoung, and O. Ribolzi. Combining multiple fallout radionuclides (137Cs, 7Be, 210Pbxs) to investigate temporal sediment source dynamics in tropical, ephemeral riverine systems. Journal of Soils and Sediments, 16(3):1130-1144, 2016. ISSN 16147480. doi: 10.1007/s11368-015-1316-y. URL http://dx .doi .org/10.1007/s11368-015-1316-y.

S. Fatichi, S. Rimkus, P. Burlando, R. Bordoy, and P. Molnar. High-resolution distributed analysis of climate and anthropogenic changes on the hydrology of an Alpine catchment. Journal of Hydrology, 525:362-382, 2015. ISSN 0022-1694. doi: 10.1016/j.jhydrol.2015.03.036. URL http://dx.doi.org/ $10.1016 / j \cdot j h y d r o l .2015 .03 .036$.

A. Francipane, V. Y. Ivanov, L. V. Noto, E. Istanbulluoglu, E. Arnone, and R. L. Bras. TRIBS-Erosion: A parsimonious physically-based model for studying catchment hydro-geomorphic response. Catena, 92:216-231, 2012. ISSN 03418162. doi: 10.1016/j.catena.2011.10.005. URL http://dx.doi.org/10. 1016/j.catena.2011.10.005.

A. Haddadchi, D. S. Ryder, O. Evrard, and J. Olley. Sediment fingerprinting in fluvial systems: Review of tracers, sediment sources and mixing models. International Journal of Sediment Research, 28(4): 560-578, 2013. ISSN 10016279. doi: 10.1016/S1001-6279(14)60013-5. URL http://dx.doi.org/10. $1016 / \mathrm{S} 1001-6279(14) 60013-5$.

M. Hinderer, M. Kastowski, A. Kamelger, C. Bartolini, and F. Schlunegger. River loads and modern denudation of the Alps - A review. Earth-Science Reviews, 118:11-44, 2013. ISSN 00128252. doi: 10.1016/j.earscirev.2013.01.001. URL http://dx.doi.org/10.1016/j .earscirev.2013.01.001.

D. J. Jerolmack and C. Paola. Shredding of environmental signals by sediment transport. Geophysical Research Letters, 37(19):1-5, 2010. ISSN 00948276. doi: 10.1029/2010GL044638.

J. Kim and V. Y. Ivanov. On the nonuniqueness of sediment yield at the catchment scale. Water Resources Research, (1):1025-1045, 2014. doi: 10.1002/2013WR014580.Received.

O. Korup, M. J. McSaveney, and T. R. Davies. Sediment generation and delivery from large historic landslides in the Southern Alps, New Zealand. Geomorphology, 61(1-2):189-207, 2004. ISSN 0169555X. doi: 10.1016/j.geomorph.2004.01.001. 
C. E. Lukens, C. S. Riebe, L. S. Sklar, and D. L. Shuster. Grain size bias in cosmogenic nuclide studies of stream sediment in steep terrain. Journal of Geophysical Research: Earth Surface, 121(5):978-999, may 2016. ISSN 2169-9003. doi: 10.1002/2016JF003859. URL https://onlinelibrary ·wiley • com/ doi/abs/10.1002/2016JF003859.

D. N. Moriasi, J. G. Arnold, M. W. V. Liew, R. L. Bingner, R. D. Harmel, and T. L. Veith. Model evaluation guidelines for systematic quantification of accuracy in watershed simulations. Transactions of the ASABE, 50(3):227-234, 2007. ISSN 16579534. doi: 10.1234/590.

O. Navratil, O. Evrard, M. Esteves, C. Legout, S. Ayrault, J. Némery, A. Mate-Marin, M. Ahmadi, I. Lefèvre, A. Poirel, and P. Bonté. Temporal variability of suspended sediment sources in an alpine catchment combining river/rainfall monitoring and sediment fingerprinting. Earth Surface Processes and Landforms, 37(8):828-846, 2012. ISSN 01979337. doi: 10.1002/esp.3201.

N. A. Niemi, M. Oskin, D. W. Burbank, A. M. Heimsath, and E. J. Gabet. Effects of bedrock landslides on cosmogenically determined erosion rates. Earth and Planetary Science Letters, 237(3-4):480-498, 2005. ISSN 0012821X. doi: 10.1016/j.epsl.2005.07.009.

K. P. Norton, F. von Blanckenburg, F. Schlunegger, M. Schwab, and P. W. Kubik. Cosmogenic nuclidebased investigation of spatial erosion and hillslope channel coupling in the transient foreland of the Swiss Alps. Geomorphology, 95(3-4):474-486, 2008. ISSN 0169555X. doi: 10.1016/j.geomorph.2007. 07.013

A. Paschalis, S. Fatichi, P. Molnar, S. Rimkus, and P. Burlando. On the effects of small scale space-time variability of rainfall on basin flood response. Journal of Hydrology, 514:313-327, 2014. ISSN 00221694. doi: 10.1016/j.jhydrol.2014.04.014. URL http://dx.doi.org/10.1016/j.jhydrol.2014.04.014.

J. D. Phillips. Evolutionary geomorphology: Thresholds and nonlinearity in landform response to environmental change. Hydrol. Earth Syst. Sci., pages 196-214, 2011. doi: 10.5194/hessd-3-365-2006.

K. Renard, G. Foster, G. Weesies, D. McCool, and D. Yoder. Predicting Soil Erosion by Water: A Guide to Conservation Planning with the Revised Universal Soil Loss Equation (RUSLE). U.S. Department of Agriculture Research Service, Washington, 1997.

L. J. Reusser and P. R. Bierman. Using meteoric 10Be to track fl uvial sand through the Waipaoa River basin, New Zealand. Geology, 38(1):47-50, 2010. ISSN 00917613. doi: 10.1130/G30395.1.

J. J. Roering, J. W. Kirchner, and W. E. Dietrich. Evidence for nonlinear, diffusive sediment transport on hillslopes and implications for landscape morphology. Water Resources Research, 35(3):853-870, 1999. ISSN 00431397. doi: 10.1029/1998WR900090. 
F. Schlunegger and H. Schneider. Relief-rejuvenation and topographic length scales in a fluvial drainage basin, Napf area, Central Switzerland. Geomorphology, 69(1-4):102-117, 2005. ISSN 0169555X. doi: 10.1016/j.geomorph.2004.12.008.

M. Schwab, D. Rieke-Zapp, H. Schneider, M. Liniger, and F. Schlunegger. Landsliding and sediment flux in the Central Swiss Alps: A photogrammetric study of the Schimbrig landslide, Entlebuch. Geomorphology, 97(3-4):392-406, 2008. ISSN 0169555X. doi: 10.1016/j.geomorph.2007.08.019.

L. Stutenbecker, R. Delunel, F. Schlunegger, T. A. Silva, B. Šegvić, S. Girardclos, M. Bakker, A. Costa, S. N. Lane, J. L. Loizeau, P. Molnar, N. Akçar, and M. Christl. Reduced sediment supply in a fast eroding landscape? A multi-proxy sediment budget of the upper Rhône basin, Central Alps. Sedimentary Geology, 375:105-119, 2018. ISSN 00370738. doi: 10.1016/j.sedgeo.2017.12.013.

L. Stutenbecker, A. Costa, M. Bakker, D. Anghileri, P. Molnar, S. N. Lane, and F. Schlunegger. Disentangling human impact from natural controls of sediment dynamics in an Alpine catchment. Earth Surface Processes and Landforms, 44(14):2885-2902, 2019. ISSN 10969837. doi: 10.1002/esp.4716.

F. Taccone, G. Antoine, O. Delestre, and N. Goutal. A gravity-driven runoff and erosion model for sediment transfers at the catchment scale. E3S Web of Conferences, 40:1-8, 2018. ISSN 22671242. doi: 10.1051/e3sconf/20184004019.

K. Tsuruta, M. A. Hassan, S. D. Donner, and Y. Alila. Development and Application of a Large-Scale, Physically Based, Distributed Suspended Sediment Transport Model on the Fraser River Basin, British Columbia, Canada. Journal of Geophysical Research: Earth Surface, 123(10):2481-2508, oct 2018. ISSN 21699003. doi: 10.1029/2017JF004578. URL http://doi.wiley.com/10.1029/2017JF004578.

J. M. Turowski, D. Rickenmann, and S. J. Dadson. The partitioning of the total sediment load of a river into suspended load and bedload: A review of empirical data. Sedimentology, 57(4):1126-1146, 2010. ISSN 00370746. doi: 10.1111/j.1365-3091.2009.01140.x.

M. Uber, C. Legout, G. Nord, C. Crouzet, F. Demory, and J. Poulenard. Comparing alternative tracing measurements and mixing models to fingerprint suspended sediment sources in a mesoscale Mediterranean catchment. Journal of Soils and Sediments, 19(9):3255-3273, sep 2019. ISSN 1439-0108. doi: 10.1007/s11368-019-02270-1. URL http://link.springer.com/10.1007/s11368-019-02270-1.

F. Van den Berg and F. Schlunegger. Alluvial cover dynamics in response to floods of various magnitudes: The effect of the release of glaciogenic material in a Swiss Alpine catchment. Geomorphology, 141-142: 121-133, 2012. ISSN 0169555X. doi: 10.1016/j.geomorph.2011.12.030. URL http://dx.doi.org/10. 1016/j .geomorph.2011.12.030. 
R. Van Dongen, D. Scherler, H. Wittmann, and F. Von Blanckenburg. Cosmogenic 10 Be in river sediment: Where grain size matters and why. Earth Surface Dynamics, 7(2):393-410, 2019. ISSN 2196632X. doi: 10.5194/esurf-7-393-2019.

A. Van Rompaey, G. Verstraeten, K. Van Oost, G. Govers, and J. Poesen. Modelling mean annual sediment yield using a distributed approach. Earth Surface Processes and Landforms, 26(11):12211236, 2001. ISSN 01979337. doi: 10.1002/esp.275.

A. Van Rompaey, P. Bazzoffi, R. J. Jones, and L. Montanarella. Modeling sediment yields in Italian catchments. Geomorphology, 65(1-2):157-169, 2005. ISSN 0169555X. doi: 10.1016/j.geomorph.2004. 08.006 .

F. von Blanckenburg. The control mechanisms of erosion and weathering at basin scale from cosmogenic nuclides in river sediment. Earth and Planetary Science Letters, 237(3-4):462-479, 2005. ISSN 0012821X. doi: 10.1016/j.epsl.2005.06.030.

D. E. Walling. Tracing suspended sediment sources in catchments and river systems. Science of the Total Environment, 344(1-3 SPEC. ISS.):159-184, 2005. ISSN 00489697. doi: 10.1016/j.scitotenv.2005.02. 011.

V. Wichmann, T. Heckmann, F. Haas, and M. Becht. A new modelling approach to delineate the spatial extent of alpine sediment cascades. Geomorphology, 111(1-2):70-78, 2009. ISSN 0169555X. doi: 10.1016/j.geomorph.2008.04.028. URL http://dx.doi.org/10.1016/j.geomorph.2008.04.028.

H. Wittmann, F. von Blanckenburg, T. Kruesmann, K. P. Norton, and P. W. Kubik. Relation between rock uplift and denudation from cosmogenic nuclides in river sediment in the Central Alps of Switzerland. Journal of Geophysical Research: Earth Surface, 112(4):1-20, 2007. ISSN 21699011. doi: 10.1029/2006JF000729.

B. J. Yanites, G. E. Tucker, and R. S. Anderson. Numerical and analytical models of cosmogenic radionuclide dynamics in landslide-dominated drainage basins. Journal of Geophysical Research: Earth Surface, 114(1), 2009. ISSN 21699011. doi: 10.1029/2008JF001088. 


\section{List of Figures}

1 Map of the landslides and incised areas in the Kleine Emme river basin. The dots indicate the location of the ${ }^{10} \mathrm{Be}$ samples that were used to derive a representative concentration for sediments mobilized by overland flow erosion $(O F)$, sediment pickup from landslides $\left(L S_{R}\right.$ and $L S_{H S}$ ) and incised areas $(I)$ (see section 2.5). In yellow are indicated the location of the ${ }^{10}$ Be sample at the outlet (dot) and the basin outlet hydrometric station (star). . . . .

2 Schematic description of the model. Sediment mobilization is possible through 4 processes: diffuse overland flow erosion $(O F)$, sediment pickup from the body of landslides by hillslope overland flow $\left(L S_{H S}\right)$, from the toe of landslides by river flow $\left(L S_{R}\right)$ and from incised areas (I). $L S_{H S}, L S_{R}$ and $I$ are activated when applied bed shear stress exceeds a threshold. On landslide surfaces the applied bed shear stress is a function of the gully width $\left(w_{L S}\right)$.

3 Calibrated simulations. Modelled hourly SSCs at the outlet (colored dots) for SIM A $(\lambda=1)$ and SIM B $(\lambda=100)$ are compared with the median (continuous line), the interquartile range (shaded area) and the $5^{\text {th }}$ and $95^{\text {th }}$ percentiles (dotted lines) of the observation. The color of the modelled SSCs represents the sediment mobilization process, or the combination of processes, producing each concentration. . . . . . . . . . . . .

4 Sediment load composition in the sensitivity analysis simulations. The percentage of yearly load generated by each sediment production process is plotted as a function of the studied parameter. On the left side of the x-axis, $\lambda, \mu$ and $k$ have the values of calibrated SIM A, and on the right side the values of calibrated SIM B. The lines are the fractions of yearly load in a simulation that has the same parameters as SIM A, except for the parameter on the x-axis. Note the reversed axis in (c). The blue square, black triangle, filled and empty red diamond indicate the fractions of yearly load of SIM B . . . . . . . . . . . . .

5 Quantification of gully development on landslides surfaces. (a, b) Hillshade of the $2 \mathrm{~m}$ resolution Lidar DEM (SwissAlti3D), (c, d) surface roughness $\sigma_{z}$ computed as the standard deviation of elevations in the Lidar DEM and $(\mathrm{e}, \mathrm{f})$ frequency distribution of $\sigma_{z}$, its mean $\mu$ and skewness $\gamma$ for a poorly gullied landslide (top row), and for a strongly gullied landslide (bottom row) in the study basin. (g) shows the $\sigma_{z}$ frequency distribution of all landslide surfaces in the basin. . . . . . . . . . . . . . . . . . . . . . . . . . 31

6 Modelled and observed ${ }^{10} \mathrm{Be}$ concentration at the outlet. (a, c) Time series of daily flow and ${ }^{10} \mathrm{Be}$ concentration with its uncertainty derived from the modelled sediment load composition for one representative year. (b, d) Frequency distribution of the hourly ${ }^{10} \mathrm{Be}$ concentrations for the simulation period 2004-2016 compared with a single observation of concentration at the outlet by Wittmann et al. [2007] . . . . . . . . . . . . . . . . . . . 32

7 Distribution of ${ }^{10} \mathrm{Be}$ concentration in potentially deposited sediment in a cross section. (a, b) Mean (square) and interquartile (wiskers) range of the modelled ${ }^{10} \mathrm{Be}$ suspended sediment concentration transported when the water level exceeds $h_{5}, h_{25}, h_{50}$ and $h_{75}$ (corresponding to the $5^{\text {th }}, 25^{\text {th }}, 50^{\text {th }}$ and $75^{\text {th }}$ percentiles of the flow distribution). (c) Elevation profile of the outlet cross section with the water depths in blue. The continuous lines indicate a fixed protected bed, the dotted line the mobile bed. . . . . . . . . . . . . . 33 
Figure 1: Map of the landslides and incised areas in the Kleine Emme river basin. The dots indicate the location of the ${ }^{10} \mathrm{Be}$ samples that were used to derive a representative concentration for sediments mobilized by overland flow erosion $(O F)$, sediment pickup from landslides $\left(L S_{R}\right.$ and $\left.L S_{H S}\right)$ and incised areas $(I)$ (see section 2.5). In yellow are indicated the location of the ${ }^{10}$ Be sample at the outlet (dot) and the basin outlet hydrometric station (star). 
Figure 2: Schematic description of the model. Sediment mobilization is possible through 4 processes: diffuse overland flow erosion $(O F)$, sediment pickup from the body of landslides by hillslope overland flow $\left(L S_{H S}\right)$, from the toe of landslides by river flow $\left(L S_{R}\right)$ and from incised areas $(I) . L S_{H S}, L S_{R}$ and $I$ are activated when applied bed shear stress exceeds a threshold. On landslide surfaces the applied bed shear stress is a function of the gully width $\left(w_{L S}\right)$. 
Figure 3: Calibrated simulations. Modelled hourly SSCs at the outlet (colored dots) for SIM A $(\lambda=1)$ and SIM B $(\lambda=100)$ are compared with the median (continuous line), the interquartile range (shaded area) and the $5^{\text {th }}$ and $95^{\text {th }}$ percentiles (dotted lines) of the observation. The color of the modelled SSCs represents the sediment mobilization process, or the combination of processes, producing each concentration. 
Figure 4: Sediment load composition in the sensitivity analysis simulations. The percentage of yearly load generated by each sediment production process is plotted as a function of the studied parameter. On the left side of the X-axis, $\lambda, \mu$ and $k$ have the values of calibrated SIM A, and on the right side the values of calibrated SIM B. The lines are the fractions of yearly load in a simulation that has the same parameters as SIM A, except for the parameter on the x-axis. Note the reversed axis in (c). The blue square, black triangle, filled and empty red diamond indicate the fractions of yearly load of SIM B. 
Figure 5: Quantification of gully development on landslides surfaces. (a, b) Hillshade of the $2 \mathrm{~m}$ resolution Lidar DEM (SwissAlti3D), (c, d) surface roughness $\sigma_{z}$ computed as the standard deviation of elevations in the Lidar DEM and (e,f) frequency distribution of $\sigma_{z}$, its mean $\mu$ and skewness $\gamma$ for a poorly gullied landslide (top row), and for a strongly gullied landslide (bottom row) in the study basin. (g) shows the $\sigma_{z}$ frequency distribution of all landslide surfaces in the basin. 
Figure 6: Modelled and observed ${ }^{10} \mathrm{Be}$ concentration at the outlet. (a, c) Time series of daily flow and ${ }^{10} \mathrm{Be}$ concentration with its uncertainty derived from the modelled sediment load composition for one representative year. (b, d) Frequency distribution of the hourly ${ }^{10}$ Be concentrations for the simulation period 2004-2016 compared with a single observation of concentration at the outlet by Wittmann et al. [2007]. 
Figure 7: Distribution of ${ }^{10} \mathrm{Be}$ concentration in potentially deposited sediment in a cross section. (a, b) Mean (square) and interquartile (wiskers) range of the modelled ${ }^{10}$ Be suspended sediment concentration transported when the water level exceeds $\mathrm{h}_{5}, \mathrm{~h}_{25}, \mathrm{~h}_{50}$ and $\mathrm{h}_{75}$ (corresponding to the $5^{\text {th }}, 25^{\text {th }}, 50^{\text {th }}$ and $75^{\text {th }}$ percentiles of the flow distribution). (c) Elevation profile of the outlet cross section with the water depths in blue. The continuous lines indicate a fixed protected bed, the dotted line the mobile bed. 


\section{${ }_{842}$ List of Tables}

1 Estimated representative ${ }^{10} \mathrm{Be}$ concentrations of sediments mobilized by the four sediment production processes. $L S_{H S}$ and $L S_{R}$ have the same concentration because they mobilize sediments from the same source. The reader is referred to the Supplementary Information for details about the derivation. . . . . . . . . . . . . . . . . . . . . 35

2 Values of the calibration parameters $k$ and $\mu$, modelled yearly load $\mathrm{Q}_{s}$, and percentages of its composition for simulations SIM A and SIM B. . . . . . . . . . . . . . . . 36

3 Model performance. $\mathrm{R}^{2}$ and model efficiency (ME) of the simulated hourly sediment load, percentage of simulated SSCs that fall within the $[5,95]^{\text {th }}$ and $[25,75]^{\text {th }}$ percentile of the observations and relative error of the modelled annual sediment yield compared with two estimates of annual load from observations (see text for explanations) . . . . . . . . . . . 37 


\begin{tabular}{cc}
\hline Mobilization process & $\begin{array}{c}{ }^{10} \text { Be Concentration } \\
{\left[10^{4} \text { at } / g_{\text {Quartz }}\right]}\end{array}$ \\
\hline$O F$ & $6.16 \pm 1.72$ \\
$L S_{H S}, L S_{R}$ & $1.60 \pm 0.75$ \\
$I$ & $0.69 \pm 0.58$ \\
\hline
\end{tabular}

Table 1: Estimated representative ${ }^{10} \mathrm{Be}$ concentrations of sediments mobilized by the four sediment production processes. $L S_{H S}$ and $L S_{R}$ have the same concentration because they mobilize sediments from the same source. The reader is referred to the Supplementary Information for details about the derivation. 


\begin{tabular}{ccccccccc}
\hline & \multicolumn{4}{c}{ Calibrated parameters } & Yearly load & \multicolumn{4}{c}{ Composition of yearly load } \\
\hline & $\lambda$ & $\mathrm{k}$ & $\mu$ & $\mathrm{Q}_{s}$ & $\mathrm{Q}_{s}(O F)$ & $\mathrm{Q}_{s}\left(L S_{R}\right)$ & $\mathrm{Q}_{s}\left(L S_{H S}\right)$ & $\mathrm{Q}_{s}(I)$ \\
& {$[-]$} & {$\left[\mathrm{kg} \mathrm{m}^{-1} \mathrm{~s}^{-1}\right]$} & {$[-]$} & {$\left[10^{5} \mathrm{t} / \mathrm{y}\right]$} & {$[\%]$} & {$[\%]$} & {$[\%]$} & {$[\%]$} \\
\hline SIM A & 1 & 0.023 & 2.5 & 2.21 & 7.73 & 11.27 & 0 & 81 \\
SIM B & 100 & $9.17 \mathrm{e}-6$ & 6 & 3.76 & 4.54 & 0 & 95.45 & 0.01 \\
\hline
\end{tabular}

Table 2: Values of the calibration parameters $k$ and $\mu$, modelled yearly load $\mathrm{Q}_{s}$, and percentages of its composition for simulations SIM A and SIM B. 


\begin{tabular}{ccccccc}
\hline & \multicolumn{2}{c}{ Hourly $\mathrm{Q}_{s}$} & \multicolumn{2}{c}{ Scatter fit [\%] } & \multicolumn{2}{c}{ Yearly load error [\%] } \\
\hline & $\mathrm{R}^{2}$ & $\mathrm{ME}$ & $5-95^{\text {th }}$ & $25-75^{\text {th }}$ & $\mathrm{Q}_{s}-\mathrm{Q}_{s_{M I N} \text { OBS }}$ & $\mathrm{Q}_{s}-\mathrm{Q}_{s_{M A X}^{O B S}}^{\text {MS }}$ \\
\hline SIM A & 0.47 & 0.32 & 89 & 49 & 198 & -22 \\
SIM B & 0.48 & 0.40 & 93 & 51 & 407 & 33 \\
\hline
\end{tabular}

Table 3: Model performance. $\mathrm{R}^{2}$ and model efficiency (ME) of the simulated hourly sediment load, percentage of simulated SSCs that fall within the $[5,95]^{\text {th }}$ and $[25,75]^{\text {th }}$ percentile of the observations and relative error of the modelled annual sediment yield compared with two estimates of annual load from observations (see text for explanations). 